\title{
Variability of Microbiota under Diverse Conditions of Soil Moistening
}

\author{
F. N. Lisetskii ${ }^{a}$ *, A. V. Zemlyakova ${ }^{a}$, and A. D. Kirichenko ${ }^{b}$ \\ ${ }^{a}$ Belgorod State National Research University, Belgorod, 308015 Russia \\ ${ }^{b}$ National Science Center Sokolovskii Institute for Soil Science and Agrochemistry Research, Kharkiv, 61024 Ukraine \\ *e-mail: liset@bsu.edu.ru \\ Received February 1, 2017
}

\begin{abstract}
According to data on the abundance of taxonomic, physiological, and ecotrophic microbial groups, analysis of the seasonal changes in their composition under conditions of artificial (irrigation) and natural (wet land formation) soil moistening was carried out. It was revealed with statistical reliability that the greatest response to changes caused by different soil moistening modes was observed in the numbers of aerobic cellulose-degrading microorganisms, denitrifiers, and fungi. An increase in erosion resistance of steppe soils during irrigation is explained by the combined effect of physicochemical and biological processes, and by higher numbers of algae, fungi, aerobic cellulose-degrading microorganisms, and oligonitrophiles, in particular.
\end{abstract}

DOI: $10.1134 / \mathrm{S} 106235901804009 \mathrm{X}$

Microorganisms and microbiological processes play an important role in the development of soil fertility and in plant nutrition (Orudzheva, 2011; Kuzyakov and Blagodatskaya, 2015). Soils, as a bioinert system and a component of the biogeocenosis, are an environment for the functioning of microorganisms. The latter play a leading role in the processes of soil formation and considerably determine the soil fertility, which is the basic characteristic of soils.

Many authors (Blagodatskii et al., 2008; Sorokin, 2009; Dobrovol'skaya et al., 2015; etc.) have shown that biochemical processes affected virtually all parameters of soil functioning, especially the upper 1 layer of soils. Microbial cenoses are extremely variable in abundance and composition, which is determined by the dynamics of the main environmental factors.

It was revealed that the activity of microflora changes under the influence of irrigation reclamation. Thus, ammonifiers and nitrifiers become more abundant, while the number of denitrifiers decreases. Azotobacter becomes significantly more numerous (Sukhova et al., 1988; Rietz and Haynes, 2003; Guo et al., 2017; etc.). Apart from this, the duration of microbiological activity increases.

When explaining the phenomenon of the increased erosion resistance of chernozem and dark chestnut soils in the south of Ukraine (Shvebs et al., 1988), a positive effect of irrigation on the microflora was revealed. Thus, the total number of microorganisms, nitrification, capacity for ammonification, nitrogen fixation, respiration, and activity of soil enzymes increased. Apart from this, it was found (Torzhevskii and Grabak, 1983) that the composition of micro- flora, as well as the direction of microbiological and biochemical processes are considerably determined by the intensity of irrigation. Thus, with an increase in irrigation rates from 500 to $1000 \mathrm{~m}^{3} /$ ha, the number of aerobic bacteria in the southern chernozems decreased twofold, accompanied by activation of anaerobic microflora (Sukhova et al., 1988).

An important component and a novelty of our research is a special study on microbiota in hydromorphic soils, which are formed with the participation of natural groundwater. Since the 1960s, changes in climatic and hydrogeological conditions in the foreststeppe and the northern steppe have resulted in the development of sporadically waterlogged areas of agrolandscapes with hydromorphic soils on slopes and even at watersheds. As a consequence of overmoisten- 2 ing, the properties, modes, and fertility of soils have been significantly transformed (Zaydel'man et al., 1998). In this case, negative effects predominate (an increase in the structure density, clods, destruction of the mineral part of the soil, accumulation of salts, etc.); i.e., the agronomic characteristics of hydromorphic soils have deteriorated.

The goal of the study was a comparative assessment of the seasonal dynamics of the microbial numbers in communities under conditions of soil irrigation and formation of hydromorphic soils outside the irrigation systems.

\section{MATERIALS AND METHODS}

Microbial communities in soils with different types of moistening were the subject of study. This study 
Table 1. Characteristics of the subjects of research

\begin{tabular}{|c|c|c|c|c|c|c|}
\hline Point & $\begin{array}{c}\text { Place } \\
\text { of sample } \\
\text { collecting }\end{array}$ & Soil & Type of land use & $\begin{array}{l}\text { Agricultural } \\
\text { background }\end{array}$ & $\begin{array}{c}\text { Soil } \\
\text { moisture, } \\
\%\end{array}$ & $\begin{array}{c}\text { Humus, } \\
\%\end{array}$ \\
\hline 1 & $\mathrm{OO}$ & Southern high-clay loamy chernozem & Nonirrigated & Sunflower & 18 & 3.1 \\
\hline 2 & $"$ & The same & Irrigated & The same & 18.2 & 3.1 \\
\hline 3 & MK & High-clay loamy carbonate chernozem & Nonirrigated & Maize & 20 & 2.1 \\
\hline 4 & $"$ & Poorly eroded & Irrigated & The same & 21.8 & 2.1 \\
\hline 5 & MK & High-clay loamy carbonate chernozem & Nonirrigated & $"$ & 18.3 & 2.9 \\
\hline 6 & $"$ & The same & Irrigated & Potatoes & 21.7 & 2.9 \\
\hline 7 & KB & Loamy dark chestnut soil & Nonirrigated & Winter wheat & 20.9 & 2.2 \\
\hline 8 & $"$ & The same & Irrigated & The same & 18.6 & 2.2 \\
\hline 9 & OK & $\begin{array}{l}\text { Common thin light-loamy poorly eroded } \\
\text { chernozem }\end{array}$ & Nonirrigated & Maize & 23.8 & 3 \\
\hline 10 & $"$ & Typical high-clay loamy wet-land chernozem & Wet land & Winter wheat & 34 & 3.7 \\
\hline 11 & $"$ & The same & $"$ & The same & 29.1 & 5.2 \\
\hline 12 & $"$ & $n$ & $"$ & $"$ & 27.2 & 5.2 \\
\hline 13 & $"$ & Meadow-chernozem heavy-clay loamy soil & $"$ & $"$ & 35.7 & 4.8 \\
\hline 14 & $"$ & Typical meadow-bog wet-land chernozem & $"$ & Deposit (sedge) & 43.7 & N.d. \\
\hline 15 & $"$ & High-clay loamy meadow-chernozem soil & $"$ & Arable land & 34.6 & 4.8 \\
\hline
\end{tabular}

Areas of sample collection: OB, Odessa oblast, Balta region; OK, Odessa oblast, Krasnoznamenka region; OO, Odessa oblast, Ovidiopol region; KB, Kherson oblast, Belozersk region (Ukraine); MK, Kaushany region (Moldova); N.d., no data.

involved irrigated soils and their nonirrigated analogues in three reclamation systems in the steppe zone (points 1, 2, and 5-8), eroded soils (points 3, 4, and 9), and hydromorphic soils in the forest-steppe zone (points 10-15) (Table 1).

In order to determine the effect of moistening in addition to the climatic norm of precipitation using land irrigation, irrigation systems under various soilclimatic conditions were selected. The studied soils of the steppe zone (i.e., common, carbonate, and southern chernozems and chestnut soils, changing from north to south) are characterized by increased aridization. This has resulted from the annual precipitation decrease in these four soil subzones, from 470 and 416 to 386 and $383 \mathrm{~mm}$, respectively. In the southern steppe and dry steppe subzones, prolonged irrigation of the land is carried out, which significantly changes the hydrothermal conditions and the biological activity of soils.

Due to the fact that redistribution of moisture is significant along the topographic gradient in the forest-steppe zone, subjects are chosen according to the catena: at the upper (points 11 and 12) and the bottom (point 10) parts of the slope.

The scheme of sample collection reflected the local differences in hydromorphic soils. The scheme was as follows: the upper (along the slope) periphery of the wet land on the arable land (point 13), its hydrocenter under conditions of fallow land use (point 14), and the bottom part of the wet land involved in arable land (point 15).

Soil samples were collected from the arable layer $(0-20 \mathrm{~cm})$ at 15 points in the dynamics of seasonal changes (spring-summer-autumn). Each sample was formed as a mixture of five individual samples. The number of waterproof aggregates was determined by the wet screening method.

In recent decades, the systematics of microorganisms has undergone significant changes due to progress in the development of chemical analysis methods and molecular biology techniques (Korshunova et al., 2015). In order to obtain the most complete picture of the response of microbiota to moisture changes in soils diverse in genesis, a study with a wide range of microorganisms was therefore carried out. This provides for the basis for subsequent study of microbial diagnostic groups. The main microbiological determinations were carried out using standard methods (Zenova and Kurakov, 1988; Metody..., 1991; Lysak et al., 2003). The analysis of the composition of taxonomic groups (bacteria, fungi, and actinomycetes), some physiological groups (nitrifiers, ammonifiers, oligonitrophiles, denitrifiers, and cellulose-degrading microorganisms), and trophic groups (oligotrophs and eutrophs) of microorganisms was carried out by inoculation of the soil suspension on solid and in liquid nutrient media (Metody..., 1991). These media were meat peptone agar (MPA) for enumeration of bacteria assimilating organic forms of nitrogen; starch ammoniac 
agar for bacteria assimilating mineral forms of nitrogen and for actinomycetes; and a sucrose-mineral Waksman-Richter medium for fungi. The coefficient of oligotrophy was defined as the ratio of the numbers of microorganisms grown on starvation agar and on MPA. Oligonitrophiles were enumerated on the Ashby medium. The numbers of nitrifiers were determined on the leached agar with ammonium-magnesium salt of phosphoric acid $\left(\mathrm{NH}_{4} \mathrm{MgPO}_{4}\right)$. Denitrifiers were enumerated on the Giltay medium, while counts of aerobic and anaerobic cellulose-degrading microorganisms were carried out on Imshenetskii and Getchinson media, respectively. Soil algae (1015 individual samples) were enumerated by the method of luminescent microscopy in freshly collected soil samples and by the Shtina-Pankratova method after incubation under optimal conditions (Shtina, 1984; Bab'eva and Zenova, 1989). To characterize the supply of soils with mineral nitrogen and the degree of the nitrification process, determination of nitrate and ammoniac nitrogen was carried out by the disulfophenol method and by an assay with Nessler's reagent, respectively. To evaluate the capacity of soils for nitrification and ammonification, the modified Waksman method was used (Fedorov, 1960).

Chemical analysis of the samples was carried out at the Laboratory of Soil Microbiology at the National Scientific Center Institute for Soil Science and Agrochemistry Research (Kharkiv, Ukraine). Statistical computation of the results was carried out using the Statistica program. To process the experimental data, the method of variance analysis was used. The classification similarity of the subjects was determined by interpreting the results of cluster analysis (Ward's method, the Euclidean distance; the values were normalized by the root-mean-square deviation).

\section{RESULTS AND DISCUSSION}

The ecological characteristics of the microbiology of soils can be determined in the spatiotemporal aspect. This can be carried out by considering the abundance of taxonomic, ecotrophic, and some physiological groups of microorganisms in the soils that differ in genesis under conditions of boghara, irrigation, and natural hydromorphism of soils, as well as during a particular season of the year.

The northernmost (of the studied) subtype of chernozems, the common chernozem (Table 2), differs from other nonirrigated chernozems (carbonate and southern chernozems) by the higher number of ammonifiers, denitrifiers, and nitrifiers, and by the capacity for ammonification. However, this chernozem is similar or inferior in the abundance of cellulose-degrading microorganisms and characterized by lower activity of the nitrification process. Carbonate chernozems, which are classified as an independent soil subtype in Moldova, are similar to southern chernozems to some extent (Lisetskii et al., 2013). A com- parison of the microbiology of all soils in Moldova (Mehtiev, 1984) showed that carbonate chernozems (with an average $2-2.5 \%$ level of $\mathrm{CaCO}_{3}$ in the upper layer) differ from the subtypes located to the north by the lower abundance of bacteria and fungi, but the larger proportion of actinomycetes. In chernozems, the content of nitrate nitrogen was higher only in the common chernozem as compared to dark chestnut soil. Nevertheless, these differences became less pronounced under conditions of irrigation.

During irrigation, the development of bacterial microflora and fungi is stimulated by high humidity in the irrigated soils (Matei et al., 2011). However, in genetically diverse soils with certain physicochemical characteristics, this occurs in different ways.

A comparison of the soils by the average seasonal abundance of the main taxonomic and trophic groups of microorganisms showed the following. Dark chestnut nonirrigated soils were similar in numbers of fungi to southern chernozems and differed significantly from other soils in the abundance of other groups of microorganisms. Particularly significant were the differences in dark chestnut nonirrigated soils in the numbers of algae, ammonifiers, and denitrifiers. Dark chestnut soils showed a higher nitrification capacity than chernozems (by $31 \%$ under conditions of boghara and by $27 \%$ under conditions of irrigation). This can be explained by the smaller range of the ratio of the carbon content in humic and fulvic acids $\left(\mathrm{C}_{\mathrm{HA}}: \mathrm{C}_{\mathrm{FA}}\right)$, which indicates greater availability of organic matter for microorganisms. Thus, microbial cells were two times more numerous in $1 \mathrm{~g}$ of humus in dark chestnut soils than in chernozem soils (Kirichenko, 1988).

The results of the variance analysis of the data on the microbiology of soils have shown that both soil moisture regulation by irrigation reclamation and seasonal dynamics (observation periods) can be considered to be significant factors affecting the soil microflora. Except for oligotrophs and actinomycetes, other groups of microorganisms respond positively to irrigation. It was mentioned (Zenova and Kurakov, 1988, Metody..., 1991) that actinomycetes had a poor response to the increase in soil moisture. Their activity is observed when conditions for the use of poorly degraded substrates are developed.

Sequential selection of the most diverse groups of microorganisms in soils under irrigation conditions and on boghara made it possible to mark out the first four groups of microorganisms presented in Table 3. The sample means for them distinguished soils at a 5\% significance level, according to the results of variance analysis. Their contribution as the factor considered in the analysis was $71 \%$. However, according to the least significant difference $\left(\mathrm{LSD}_{05}\right)$, only anaerobic cellulose-degrading microorganisms, denitrifiers, and fungi became significantly more numerous during the year in irrigated soils, in comparison with nonirrigated analogues. 
Table 2. The numbers of algae (autumn), ammonifying microorganisms, nitrifiers, and denitrifiers, and activity of ammonification/nitrification processes (average for the season)

\begin{tabular}{|c|c|c|c|c|c|c|c|c|}
\hline \multirow[t]{2}{*}{ Point } & \multirow[t]{2}{*}{$\begin{array}{c}\text { Algae } \\
\text { in } 0 \text { - to } 2-\mathrm{cm} \text { layer, } \\
\text { thousand } / \mathrm{g}\end{array}$} & Ammonifiers & Denitrifiers & $\begin{array}{c}\text { Ammonificat } \\
\text { ion capacity } \\
\mathrm{N}-\mathrm{NH}_{4}\end{array}$ & $\begin{array}{c}\text { Nitrification } \\
\text { capacity } \\
\mathrm{N}-\mathrm{NO}_{3}\end{array}$ & $\begin{array}{l}\text { Mobile } \\
\text { nitrogen }\end{array}$ & \multirow[t]{2}{*}{$\begin{array}{c}\text { Nitrifiers, } \\
\text { thousand/ } \\
1 \mathrm{~g}\end{array}$} & \multirow[t]{2}{*}{$\begin{array}{l}\text { Oligotrophy } \\
\text { coefficient }\end{array}$} \\
\hline & & \multicolumn{2}{|c|}{ million/1 g soil } & \multicolumn{3}{|c|}{$\mathrm{mg} / 100 \mathrm{~g}$ absolutely dry soil } & & \\
\hline 1 & 2.4 & 3 & 9.3 & 0.7 & 2.6 & 0.5 & 2.1 & 2.2 \\
\hline 2 & 2.9 & 3.7 & 27.5 & 1.1 & 3 & 0.6 & 3.2 & 1.3 \\
\hline 3 & 2.3 & 3.5 & 5.8 & 0.7 & 2.7 & 0.6 & 1.9 & 1.8 \\
\hline 4 & 3.1 & 5.9 & 39.7 & 1 & 2.6 & 0.7 & 2.4 & 0.9 \\
\hline 5 & 29.3 & 3 & 6.7 & 1.1 & 2.9 & 0.4 & 1.6 & 2.2 \\
\hline 6 & 2.8 & 4.3 & 18.3 & 1.5 & 3 & 0.5 & 2.7 & 1.6 \\
\hline 7 & 33 & 7.3 & 24.9 & 1.5 & 3.7 & 0.7 & 2.9 & 1.5 \\
\hline 8 & 42.3 & 7.6 & 62.8 & 2.1 & 3.9 & 0.6 & 2.9 & 1.4 \\
\hline 9 & 22.1 & 4.5 & 8.9 & 1.2 & 2.2 & 0.6 & 2.9 & 1.6 \\
\hline 10 & 28.2 & 5.7 & 9.4 & 1 & 3.5 & 0.4 & 2.1 & 0.9 \\
\hline 11 & 8.3 & 6.9 & 32.2 & 1 & 3.4 & 0.7 & 3.4 & 0.9 \\
\hline 12 & 21.3 & 6.8 & 12.1 & 0.7 & 3.1 & 0.8 & 3.5 & 1.3 \\
\hline 13 & 20.7 & 7.4 & 19.9 & 1.1 & 3.4 & 0.5 & 2.8 & 2.2 \\
\hline 14 & 35 & 12.7 & 107.6 & 0.8 & 1.7 & 0.9 & 1.2 & 2.8 \\
\hline 15 & 41.4 & 13.7 & 63.4 & 1.5 & 1.8 & 0.8 & 1.9 & 2.6 \\
\hline
\end{tabular}

Table 3. Microbiological indices of nonirrigated and irrigated soils of the steppe zone and the value of the coefficient of the excess number of microorganisms under irrigated conditions relative to the nonirrigated analogues $\left(K_{\text {ir }}\right)$

\begin{tabular}{l|c|c|c|c|c}
\hline \multirow{2}{*}{ Group of microorganisms } & \multicolumn{2}{|c}{ Soil } & \multicolumn{3}{c}{$K_{\text {ir }}$} \\
\cline { 2 - 6 } & nonirrigated & irrigated & spring & summer & autumn \\
\hline Cellulose-degrading anaerobic* & 21.7 & $52.2^{* * *}$ & 2.13 & 4.45 & 4.54 \\
Denitrifiers* & 11.7 & $37.1^{* * *}$ & 4.65 & 4.57 & 2.78 \\
Fungi** & 34.5 & $57.5^{* * *}$ & 2.14 & 1.7 & 1.36 \\
Bacteria assimilating mineral nitrogen* & 16.7 & 19.6 & 1.43 & 1.39 & 2.47 \\
Cellulose-degrading aerobic** & 41.4 & 57.9 & 1.41 & 1.71 & 1.55 \\
Bacteria assimilating organic nitrogen* & 4.5 & 5 & 1.32 & 1.24 & 1.2 \\
Nitrifiers** & 2.1 & 2.8 & 1.41 & 1.3 & 1.65 \\
Actinomycetes* & 4.4 & 4.8 & 1.24 & 1.4 & 1.09 \\
Oligonitrophiles* & 40.6 & 51.8 & 1.48 & 1.3 & 1.22 \\
Oligotrophs* & 40.2 & 34 & 0.88 & 0.96 & 0.84 \\
Average & & & 1.85 & 2.08 & 1.89 \\
\hline
\end{tabular}

* Million/g; for Tables 3 and 4. ** Thousand/g; for Tables 3 and 4. ${ }^{* * *}$ The difference is significant according to LSD $_{05}$.

The role of irrigation can be most correctly evaluated by comparing analogous subjects (points 2 and 1 , 4 and 3,6 and 5, and 8 and 7). Using the data on the paired ratios of the numbers of microorganisms during three seasons, the highest microbial abundance was revealed for denitrifiers during irrigation reclamation (Table 3). On average for the seasons, the coefficient of the excess number of denitrifiers in irrigated soils in comparison with their nonirrigated analogues $(n=12)$ was $4 \pm 0.9(p=0.95)$. Taking into account the seasonal variability, the average coefficient of the excess number of cellulose-degrading anaerobes in irrigated soils was $3.9 \pm 1.2(p=0.95)$ as compared to their nonirrigated analogues. In other groups of microorganisms (except for oligotrophs), the abundance excess due to irrigation was similar (Table 3), $1.5 \pm 0.2$ times 
higher $(p=0.95)$, on average. Thus, aerobic cellulosedegrading microorganisms and oligonitrophiles responded positively to irrigation, which resulted in their higher abundance $(1.56 \pm 0.36$ and $1.33 \pm 0.18$ times $(p=0.95)$, respectively, taking seasonal cycles into account), than in nonirrigated soils.

Irrigation affected the number of microorganisms participating in the transformation of nitrogen compounds, as well as the content of mobile nitrogen forms and the potential capacity of soils for ammonification and nitrification processes. The number of ammonifying bacteria was higher (by 24-44\%) in irrigated soils in all variants and virtually during all the observation periods, especially in autumn. Higher numbers of ammonifiers resulted in an increase in the capacity to mobilize soil nitrogen by $30-50 \%$, on average, for irrigated variants, due to proteolysis and deaminization. This is a prerequisite for an increase in the content of nitrogen in the form of ammonium in the irrigated soil.

Sporadic anaerobiosis during irrigation is intensified from spring to autumn, when it is mostly pronounced, which is evident from the increased number of cellulose-degrading anaerobes. The aforementioned characteristics of the development of microflora in irrigated soils are observed throughout the whole vegetative period. An exception is dark chestnut soil, where the moisture level of the nonirrigated soil was higher than that of the irrigated soil during the summer period. Due to significant precipitation, irrigation was not carried out and the location of the nonirrigated area promoted greater accumulation of moisture in the soil. Denitrifiers were 2-4 times more numerous, and the number of anaerobic cellulosedegrading microorganisms was two times higher in the irrigated dark chestnut soil in spring and summer.

In the previous comparison of chernozems with various carbonate contents (Zakharov, 1978), it was shown that the total abundance of the cellulose microflora in chernozem without carbonates was higher than that with carbonate. This was confirmed by our data as well. For instance, the number of cellulosedegrading aerobic and anaerobic microorganisms was 2.2 and 1.4 times higher, respectively, in common chernozem than in carbonate chernozem in autumn. Under irrigation conditions, this excess is retained only for anaerobic microorganisms. On average for three seasons, the number of fungi during irrigation of carbonate chernozems was 1.6-1.9 times higher than on boghara. During all seasons, but especially in summer, when the effect of irrigation reclamation increased, the numbers of cellulose-degrading aerobic and anaerobic microorganisms were more than two times higher during irrigation of carbonate chernozems than in their nonirrigated analogues.

By the time of sample collection in spring, irrigation still had not been carried out in any reclamation systems, and, thus, the soil moisture in the irrigated and nonirrigated areas was similar. Nevertheless, the differences in the microflora composition reflected those stable changes that persisted in soil under the influence of the previous irrigation. The data obtained in spring before the beginning of irrigation showed that irrigation had a prolonged effect on the taxonomic composition of the microbial cenosis and the trophic mode of soils. Thus, an increase in the number of eutrophic microflora and a significant decrease in the oligotrophy of the cenosis were observed, which indicated a better trophic mode in irrigated soils. The values of the total number of eutrophs during the vegetation period in irrigated soils are $1.4 \pm 0.31$ times $(p=0.95)$ higher than the values observed for soils of nonirrigated analogues. If the coefficient of oligotrophy in nonirrigated soils is considered $100 \%$, its value in relative terms for irrigated soils, taking the annual dynamics into account, will be $70 \pm 20 \%(p=0.95)$.

The annual variability in the numbers of microorganisms, which can be expressed using the coefficient of variation $(V, \%)$, makes it possible to determine the groups most sensitive to changes in hydrothermal conditions. According to the annual variability, microorganisms can be assigned to three groups: bacteria assimilating organic nitrogen, oligonitrophiles, and cellulose-degrading aerobic bacteria, with insignificant variation $(V<10 \%)$; actinomycetes and nitrifiers, with medium variation $(V=10-20 \%)$; fungi, denitrifiers, oligotrophs, bacteria assimilating mineral nitrogen, and cellulose-degrading anaerobic microorganisms, with significant variation $(V>20 \%)$.

The most pronounced changes in the number of microorganisms (in the ten main groups) were observed in summer $(V=65 \%)$, and slightly lower $V$ values were observed in spring $(57 \%)$ and in autumn $(56 \%)$. Thus, the variability was significant during all seasons.

According to the results of variance analysis, the seasonal differences in the numbers of microorganisms were reliable $\left(F_{\mathrm{f}}>F_{05}\right)$ for four groups of microorganisms (Table 3). They can be defined as the groups most sensitive to the changes in soil moistening (anaerobic cellulose-degrading microorganisms, denitrifiers, bacteria assimilating mineral nitrogen, and fungi).

Unidirectional changes from season to season were determined for five groups of microorganisms (Table 3). At the same time, from spring to summer and to autumn, the numbers of denitrifiers, fungi, oligonitrophiles, and bacteria assimilating organic nitrogen decreased and only the number of anaerobes increased. In addition, the abundance of ammonifiers naturally increased from spring to summer and to autumn: from $3.2 \pm 0.83$ and $4.53 \pm 1.54$ to $6.62 \pm$ 3.15 million/ $1 \mathrm{~g}$ soil $(p=0.95)$, respectively.

In contrast to nonirrigated soils, when the 0.5 - to $0.25-\mathrm{mm}$ fraction prevails in the structure, a significant shift to larger fractions of water resistant aggre- 
Table 4. Differences in the microbiological indices of eroded and wet-land soils of the forest-steppe zone

\begin{tabular}{|c|c|c|c|c|c|c|c|}
\hline \multirow{2}{*}{ Group of microorganisms } & \multicolumn{3}{|c|}{ Catena } & \multicolumn{3}{|c|}{ Wet land } & \multirow{2}{*}{$\begin{array}{l}\text { The difference } \\
\text { between the } \\
\text { points } 14 \text { and } 13\end{array}$} \\
\hline & 10 & 11 & 12 & 13 & 14 & 15 & \\
\hline Denitrifiers* & 9.4 & 32.2 & 12.1 & 19.9 & 107.6 & 47.6 & $87.7 * * *$ \\
\hline Cellulose-degrading anaerobic* & 79.8 & 41.5 & 42.8 & 57.9 & 92.6 & 67.8 & $34.7 * * * *$ \\
\hline Oligotrophs* & 28.8 & 53.5 & 43.4 & 53.3 & 67.4 & 80.6 & 14.1 \\
\hline Oligonitrophiles* & 39.5 & 87 & 84.3 & 67.5 & 77.1 & 194 & 9.6 \\
\hline Bacteria assimilating organic nitrogen* & 5.7 & 6.9 & 6.8 & 7.4 & 12.6 & 16.1 & 5.2 \\
\hline Actinomycetes* & 6.3 & 4.8 & 7.7 & 4.5 & 5.8 & 3.6 & 1.3 \\
\hline Bacteria assimilating mineral nitrogen* & 20.6 & 26.4 & 17.1 & 13.5 & 13.8 & 11.9 & 0.3 \\
\hline Nitrifiers** & 2.16 & 3.44 & 3.46 & 2.85 & 1.2 & 1.9 & -1.7 \\
\hline Fungi** & 39.1 & 23.3 & 32.4 & 24.0 & 18.1 & 21.4 & -5.9 \\
\hline Cellulose-degrading aerobic* & 33.4 & 50.2 & 45.4 & 45.2 & 36.4 & 63.8 & -8.8 \\
\hline
\end{tabular}

***, **** The difference is significant at the $1 \%$ and $5 \%$ significance levels, respectively.

gates $(2-1,1-0.5$ and slightly less for the $3-$ to $2-\mathrm{mm}$ fraction) is typical for irrigated analogues. It can be assumed that the increase in the water resistance of aggregates and erosion resistance revealed during irrigation of steppe soils (Shvebs et al., 1988; Bulygin and Lisetskiy, 1992) is a result of not only an increase in soil microaggregation, but of more intensive microbiological activity as well.

As was previously shown during the study of microbial communities in the southern chernozem (Sukhova et al., 1988), the consequences of irrigation are poorly related to changes in the composition of bacterial communities, populations of actinomycetes, in particular. On the contrary, algae are sufficiently sensitive to changes that are caused by irrigation. The data obtained on algosinusia in the studied soils (Table 2) indicate that the most favorable conditions for the development of algoflora were developed in autumn. This was facilitated by good moistening of the soil $(21-24 \%)$ and by the supply of soils of agrocenoses with fresh plant matter. In this case, the effect of irrigation in autumn was leveled. When comparing irrigated soils and their analogues on boghara, the highest number of algae was observed in dark chestnut soil in winter wheat sowing (33000-42000/g). In irrigated soils, microbial communities may promote soil binding and its structural stability in the 0 - to $5-\mathrm{cm}$ layer (Caesar-Tonthat et al., 2014). Therefore, soil algae were enumerated in the 0 - to $2-\mathrm{cm}$ layer. The effect of erosion resistance of soil algae was observed in aggregation of the soil particles due to mucous substances, while the interlacing threads of algae mechanically fixed them. The experiments (Marathe, 1972) suggested that soil algae reinforced the aggregation of soil particles by $36-78 \%$, depending on the type of soil. The formation of the soil structure and an increase in soil stability were also associated with the vital activity of fungi, oligonitrophiles, and cellulose-degrading bacteria. In the irrigated soils, the number of oligonitrophiles carrying out nitrogen fixation processes increases. Oligonitrophiles are characterized by an increased mucus production capacity and participate in the formation of the soil structure, together with fungi (Sushkina and Tsyurupa, 1973). Since the members of these groups of microorganisms respond positively to irrigation, it is their influence that can explain the previously revealed (Shvebs et al., 1988) increase in soil erosion resistance under the conditions of irrigation.

Destruction of cellulose by microorganisms is related to the processes of humus development and formation of the water resistant structure of soils. This process is carried out by the mixture of specific microorganisms (fungi and bacteria, including actinomycetes), characterized by different requirements for environmental factors. Thus, aerobic cellulosedegrading microorganisms responded positively to irrigation; their average abundance was $40 \%$ higher than that on the boghara. Hence, transformation of plant matter is more intensive during irrigation, which undoubtedly affects the processes of structure formation and the water-retaining capacity of soils.

Using the results of cluster analysis with the data from Table 4, microorganisms can be classified into three groups with the main complexes of microbiological processes under conditions of natural soil hydromorphism. These are actinomycetes, nitrifiers, and bacteria assimilating organic nitrogen; fungi and bacteria assimilating mineral nitrogen; and other groups with indirect participation of oligonitrophiles.

Comparison of the width of the $95 \%$ confidence interval for the average values of abundance of ten groups of microorganisms in all hydromorphic soils (Table 4) with the values in the hydrocenter of the wet land (point 14) indicated the following. Under conditions of excessive soil moistening throughout the year, 
significantly lower values were observed for nitrifiers and cellulose-degrading aerobic microorganisms and higher values were registered for denitrifiers and anaerobic microorganisms.

Hydromorphic soils are characterized by a high number of ammonifiers; mineral nitrogen is represented mainly by the ammonium form. In the hydrocenter of the wet land (point 14), the highest abundance of functional groups such as oligonitrophiles and denitrifiers, was detected in spring. Anaerobic processes are activated, and the number of aerobes decreases under conditions of high values of humidity and temperature in the hydrocenter of the wet land in summer. At the same time, high values of the oligotrophy coefficient are indicative of unfavorable conditions for the microbial cenosis, since the value of soil moisture exceeds the optimal one. In hydromorphic soils, the number of soil algae was at its maximum $(21000-41000 / \mathrm{g})$ in autumn. In the hydrocenter of the wet land, development of algae was also observed in spring and summer, but at a very low level (0.10.2 thousand/g). Nevertheless, under conditions of optimal moistening of the forest-steppe, differences in the abundance of all major groups of microorganisms in the upper parts (points 11 and 12) and the lower parts (point 10) of the slope, differing in the level of soil erosion, were revealed (Table 4). According to the results of variance analysis on the basis of the average seasonal data, the position in the relief (points 1015 ) is an insignificant factor for the differentiation of the number of microorganisms in hydromorphic soils. According to the results of cluster analysis of five hydromorphic soils by the numbers of ten groups of microorganisms, the most distinctive (regarding classification) subject was revealed. Comparison of the latter with the hydrocenter of the wet land (point 14) makes it possible to determine the most pronounced effect of excessive soil moistening on the microflora. Such an original subject is the arable soil of the meadow chernozem with a medium alkaline reaction of the soil solution ( $\mathrm{pH}$ 8.2), which is located at the periphery of the wet land (point 13). The differences between points 14 and 13 (Table 4) are most significantly related (taking into account seasonal cycles) to the numbers of denitrifiers $(p=0.99)$ and cellulosedegrading anaerobic microorganisms in spring and summer $(p=0.95)$. Thus, first of all, the more intensive development of these two groups of microorganisms makes the microbiological characteristics of irrigated and hydromorphic soils similar.

\section{CONCLUSIONS}

Analysis of a wide range of data on the microbiology of soils under various moistening conditions has shown that both modes of moistening and the annual dynamics of changes in hydrothermal conditions are significant factors affecting soil microflora.
Analysis of the taxonomic and functional characteristics of the microbial cenosis in irrigated soils indicate significant changes that may persist in the absence of irrigation, but under favorable weather conditions.

The revealed interseasonal differences in the numbers of microorganisms have made it possible to determine the groups of microorganisms most sensitive to the changes in soil moistening conditions due to reclamation. These were anaerobic cellulose-degrading microorganisms, denitrifiers, fungi, and bacteria assimilating mineral nitrogen.

In irrigated soils, in comparison with nonirrigated analogues, a higher abundance of anaerobic cellulosedegrading microorganisms, denitrifiers, and fungi was reliably revealed throughout the year (under conditions of high interseasonal variability of microbiological indices). Their numbers in irrigated soils may be a test indicator of changes in the hydrothermal conditions.

Reclamation regulation of the moisture of steppe soils and natural hydromorphism in the forest-steppe affect the soil microbiota in a similar way. Thus, the differences are close $(<40 \%$ when the relative units of comparison are used) for six microbiological indices out of ten. However, nitrifiers, fungi, and anaerobes are more numerous in irrigated soils than in the hydrocenter of the wet land. The latter differs in a single indicator, a higher number of denitrifiers.

The higher erosion resistance of irrigated soils, as compared to nonirrigated analogues, is explained by the combined action of physicochemical and biological processes, by improved water resistance of the structure (due to the increase in size from $0.5 \mathrm{~mm}$ and the medium diameter of aggregates), in particular. It is also explained by stable changes in the numbers of some microbial groups, which can be presented in the ranked descending series: algae $>$ fungi $>$ aerobic cellulose-degrading microorganisms $>$ oligonitrophiles. Further study of the members of these groups of microorganisms is of importance in order to solve the problems of assessment of resistance to soil erosion during irrigation of inclined lands and when there is a risk of development of erosion due to irrigation.

\section{ACKNOWLEDGMENTS}

This study was supported by the Ministry of Science and Education of the Russian Federation (the 2017-2019 state assignment for the Belgorod State National Research University, project No. 5.4711.2017/6.7).

\section{REFERENCES}

Bab'eva, I.P. and Zenova, G.M., Biologiya pochv (Soil Biology), Moscow: Izd. MGU, 1989.

Blagodatskii, S.A., Blagodatskaya, E.V., and Bogomolova, I.N., Microbial biomass and growth kinetics of microorganisms 
in chernozem soils under different land use modes, Microbiology, 2008, vol. 77, no. 1, pp. 99-106.

Bulygin, S.Yu. and Lisetskiy, F.N., Soil microaggregation as an index of erosion resistance, Euras. Soil Sci., 1992, vol. 24 , no. 3 , pp. $59-65$.

Caesar-Tonthat, T., Stevens, W.B., Sainju, U.M., Caesar, A.J., West, M., and Gaskin, J.F., Soil-aggregating bacterial community as affected by irrigation, tillage, and cropping system in the northern great plains, Soil Sci., 2014, vol. 179, no. 1 , pp. $11-20$.

Dobrovol'skaya, T.G., Zvyagintsev, D.G., Chernov, I.Y., Golovchenko, A.V., Zenova, G.M., Lysak, L.V., Manucharova, N.A., Marfenina, O.E., Polyanskaya, L.M., Stepanov, A.L., and Umarov, M.M., The role of microorganisms in the ecological functions of soils, Euras. Soil Sci., 2015, vol. 48, no. 9, pp. 959-967.

Fedorov, M.V., Mikrobiologiya (Microbiology), Moscow: Gossel'khozizdat, 1960.

Guo, W., Andersen, M.N., Qi, X.-B., Li, P., Li, Z.-Y., Fan, X.-Y., and Zhou, Y., Effects of reclaimed water irrigation and nitrogen fertilization on the chemical properties and microbial community of soil, J. Integr. Agricult., 2017, vol. 16 , no. 3, pp. 679-690.

Kirichenko, A.D., Microflora, microbiological processes, and their evolution under intensive agricultural use of soils, in Pochvy Ukrainy i povyshenie ikh plodorodiya (Soils of Ukraine and Improvement of Their Fertility), Kiev: Urozhai, 1988, vol. 1, pp. 82-94.

Korshunova, T.Y., Mukhamatdyarova, S.R., and Loginov, O.N., Taxonomic classification of the oil destructing bacterium using mass spectrometry methods by the results of analysis of cellular proteins and study of cellular fatty acids, Biol. Bull., 2015, vol. 42, no. 3, pp. 220-225.

Kuzyakov, Y. and Blagodatskaya, E., Microbial hotspots and hot moments in soil: concept and review, Soil Biol. Biochem., 2015, vol. 83, pp. 184-199.

Lisetskii, F.N., Goleusov, P.V., and Chepelev, O.A., The development of chernozems on the Dniester-Prut interfluve in the Holocene, Euras. Soil Sci., 2013, vol. 46, no. 5, pp. 491-504.

Lysak, L.V., Dobrovol'skaya, T.G., and Skvortsova, I.N., Metody otsenki bakterial'nogo raznoobraziya pochv $i$ identifikatsii pochvennykh bakterii (Methods for Evaluating the Diversity and Identification of Soil Bacteria), Moscow: MAKS-Press, 2003.

Marathe, K.V., Role of some blue-green algae in soil aggregation. The taxonomy and biology of blue-green algae, in Proc. Sympos. Taxon. Boil. Blue Green Algae, Madras: Madras Univ., 1972, pp. 328-331.

Matei, G.-M., Matei, S., Seceleanu, I., Mocanu, V., Dumitru, S., and Cotet, V., Influence of irrigation on microbial communities and soil organic matter evolution in the Chernozem in Marculesti, J. Environ. Protect. Ecol.,

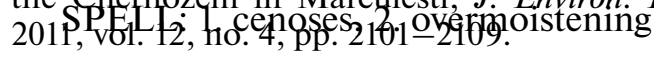

Mekhtiev, S.Ya., Microflora and other biological indicators, in Pochvy Moldavii (Soils of Moldova), Chisinau: Shtiintsa, 1984, vol. 1, pp. 136-140.

Metody pochvennoi mikrobiologii i biokhimii (Methods of Soil Microbiology and Biochemistry), Zvyagintsev, D.G., Ed., Moscow: Izd. MGU, 1991.

Orudzheva, N.I., Microbiological characteristics of different types of irrigated soils in the subtropical zone of Azerbaijan, Euras. Soil Sci., 2011, vol. 44, no. 11, pp. 1241-1249.

Polyanskaya, L.M., Ivanov, K.E., Guzev, V.S., and Zvyagintsev, D.G., Estimation of abundance dynamics of gram-negative bacteria in soil, Microbiology, 2008, vol. 77, no. 6 , pp. $760-764$.

Rietz, D.N. and Haynes, R.J., Effects of irrigation-induced salinity and sodicity on soil microbial activity, Soil Biol. Biochem., 2003, vol. 35, no. 6, pp. 845-854.

Shtina, E.A., Methods for studying soil algae, in Mikroorganizmy kak komponent biogeotsenoza (Microorganisms of a Biogeocoenosis Component), Moscow: Nauka, 1984, pp. 58-74.

Shvebs, G.I., Svetlichnyy, A.A., and Chernyy, S.G., Soil resistance to erosion in the southern Ukraine and change therein due to irrigation, Soviet Soil Sci., 1988, vol. 20, no. 4, pp. 68-74.

Sorokin, N.D., Microbiological monitoring of disturbed ground ecosystems of Siberia, Biol. Bull., 2009, vol. 36, no. 6, pp. 619-623.

Sukhova, S.N., Zenova, G.M., Zborishchuk, N.G., and Zvyagintsev, D.G., Microbial communities of southern black earth soils as an indicator of irrigation consequences, Pochvovedenie, 1988, no. 11, pp. 82-85.

Sushkina, N.N. and Tsyurupa, I.G., Mikroflora i pervichnoe pochvoobrazovanie (Microflora and Primary Soil Formation), Moscow: Izd. MGU, 1973.

Torzhevs'kii, V.I. and Grabak, N.Kh., Influence of soil cultivation methods on the microflora of southern black earth soils, Agrokhim. Gruntoznavstvo, 1983, no. 46, pp. 66-70.

Zaidel'man, F.R., Tyul'panov, V.I., Angelov, E.N., and Davydov, A.I., Pochvy mocharnykh landshaftov - formirovanie, agroekologiya $i$ melioratsiya (Soils of Damped Meadow Landscapes-Formation, Forming, Agroecology, and Reclamation), Moscow: Izd. MGU, 1998.

Zakharov, I.S., Obrazovanie gumusovykh veshchestv tsellyulozorazrushayushchimi mikroorganizmami (Production of Humic Substances by Cellulolytic Microorganisms), Chisinau: Shtiintsa, 1978.

Zenova, G.M. and Kurakov, A.V., Metody opredeleniya struktury kompleksov pochvennykh aktinomitsetov $i$ gribov (Methods for Determining the Structure of Complexes of Soil Actinomycetes and Fungi), Moscow: Izd. MGU, 1988.

Translated by A. Panyushkina 